This is an author produced version of a paper published in Journal of Corporate Real Estate. This paper has been peer-reviewed but does not include the final publisher proof-corrections or journal pagination.

Citation for the published paper:

Berthelsen, Hanne; Muhonen, Tuija; Toivanen, Susanna. (2018). What happens to the physical and psychosocial work environment when activity-based offices are introduced into academia?. Journal of Corporate Real Estate, vol. 20, issue 4, p. null

URL: https://doi.org/10.1108/JCRE-06-2017-0017

Publisher: Emerald

This document has been downloaded from MUEP (https://muep.mah.se) / DIVA (https://mau.diva-portal.org). 


\title{
What happens to the physical and psychosocial work environment when activity-based offices are introduced into academia?
}

\author{
Hanne Berthelsen ${ }^{1}$,Tuija Muhonen ${ }^{1} \&$ Susanna Toivanen $^{2,3}$ \\ ${ }^{1}$ Centre forWork Life and Evaluation Studies, Malmö University, Malmö, Sweden \\ ${ }^{2}$ Academy of Health, Care and Social Welfare, Mälardalen University, Västerås, \\ ${ }^{3}$ Sweden and Department of Public Health Sciences, Stockholm University, Sweden
}

\begin{abstract}
Purpose - Activity-based offices are still uncommon at universities, but there is an increase in their popularity now. The purpose of this study is to contribute to the knowledge about the importance of the physical work conditions for the psychosocial work environment within academia by analyzing how staff at a large Swedish university experienced the physical and psychosocial work environment before and after moving to activity-based offices.
\end{abstract}

Design - A web-based survey was distributed to all employees at two faculties at a university three months before $(2015, \mathrm{n}=217$, response rate $51 \%)$ and nine months after $(2016, \mathrm{n}=200$, response rate $47 \%$ ) relocation to a new activity-based university building.

Findings - In the new premises, a vast majority (86\%) always occupied the same place if it was vacant. Employees were working more often from home, which in turn may lead to further deterioration of the psychosocial work environment. Social community at work had declined and social support from colleagues and supervisors was perceived to have decreased. Participants were more likely to seek new jobs, and also job satisfaction was lower. No aspects in the physical or psychosocial work environment were perceived to have improved after the relocation.

Research limitations - The study had a two-wave cross-sectional design, which does not allow establishing causal relations.

Practical implications - There is reason to be cautious about relocation to activity-based offices at universities. The savings that the organization may make in costs for premises may lead to costs in other ways. The risk that staff cannot concentrate on their work in activity-based university workplaces and lose their sense of community with colleagues are factors which in the long run may lead to decreased efficiency, more conflicts and poorer well-being.

Originality - This paper contributes new knowledge concerning changes in the physical and psychosocial work environment when relocating from cell offices to activity-based offices in a university setting.

Keywords Activity-based offices, university, physical work environment, psychosocial work environment, social relations, COPSOQ 
Paper type Research paper 


\section{What happens to the physical and psychosocial work environment when activity-based offices are introduced into academia?}

\section{Introduction}

Activity-based offices are still uncommon for academics and teachers, but now several universities seem to be introducing this type of workplaces. Academic work typically requires opportunities for networking as well as undisturbed working conditions with easy access to working material such as books or notes. However, there is limited knowledge about what happens when staff move from their own rooms to activity-based offices in academia, and sparse empirical findings on how staff experience the working environment in this new kind of office environment (Van der Voordt 2004). This article presents results from a survey conducted before and after a move from cell offices to activity-based offices at a Swedish university.

Technological development enables office workers to work virtually anywhere and at any time with the help of computers and smartphones. Hence, work is no longer done at a place an employee goes to. This has led to decreasing occupancy rates at office workplaces and has highlighted the need for optimizing the use of office space. As the future sustainable office type, the promotion of so-called activity-based offices has increased in Sweden during the past few years (Gunne 2013, Toivanen 2015). This development can also be seen as a way for businesses to reduce office space and save money while flexible open plan offices can more easily adapt to future changing needs (Gunne 2013). Preliminary results from an ongoing research project suggest, however, that activity-based offices do not fit all types of activities (Slunga Järvholm 2016). It appears that work requiring concentration is less suitable in open offices where disturbances mainly from the acoustic environment are apparent and there are often no quiet environments (De Been \& Beijer 2014, Gensler 2012, Seddigh et al. 2015). It can therefore be questioned whether employee performance and comfort are compromised in the pursuit of space-optimized, flexible office workplaces.

\subsection{Office Types}

There are a number of different types of office environments. Within research, offices are classified as a) cell offices (own or shared room for one to three people), and b) different types of open offices (mainly small, medium-sized, and large open plan offices, and activity based offices: combi offices and flex offices (Bodin Danielsson \& Bodin 2008, Bodin Danielsson et al. 2014). In the open plan office, employees are positioned at permanent workstations, while in a combi office, employees have permanent workstations, but work is also conducted in shared spaces adjacent to their own workstation. However in the flex office employees do not have permanent workstations (Bodin Danielsson \& Bodin 2008, Appel-Meulenbroek et al. 2011, Kim et al. 2016), and there is usually space for about $70 \%$ of the staff at the same time (Bodin Danielsson \& Bodin 2008). The open office space in an activity-based flex office is divided into zones based on the most common activities of the company. The employees do not have fixed workstations but are expected to switch between different workstations in line with the needs of their current task (Appel-Meulenbroek et al. 2011). The design of activity-based offices is said to be based on employee needs: "In the best of worlds, employees should have more choices and tools for everything they need to do in a day, get together, feel better, have fun at work and perform better' (Gunne 2013, page 34). This study addresses a relocation of university staff from cell offices to activity-based offices.

\subsection{Office type, work environment and employee well-being}

The office environment is important for various aspects of employee well-being, e.g. health and sick leave (Pejtersen et al. 2011, Bodin Danielsson et al. 2014), job satisfaction (Bodin Danielsson 
\& Bodin 2008) and the occurrence of workplace conflicts (Bodin Danielsson et al. 2015). Furthermore, the office environment may affect factors that are important for organizational success, e.g. employee performance (Jahncke et al. 2011, Seddigh et al., Seddigh et al. 2015; Kupritz 2001).

The acoustic environment is often perceived as disturbing in open plan offices, particularly in medium-sized and large open plan offices (Bodin Danielsson \& Bodin 2009). Experimental research shows that office environments with a high noise level negatively affect participants' memory performance and lead to increased fatigue and lower job motivation (Jahncke et al. 2011). Employees with tasks characterized by a need for concentration tend to report more distraction if working in other types of offices than cell offices, and also more cognitive stress in all office types except cell offices and flex offices (Seddigh et al. 2014). Moreover, high noise levels can increase the occurrence of conflicts in office workplaces (Bodin Danielsson et al. 2015).

Cell office outweighs the open plan office in terms of satisfaction with most aspects of the indoor environment, particularly the acoustic environment and the ability to withdraw when needed. The benefits of potentially improved communication in the open plan office are fewer than the health and performance disadvantages arising from increased noise levels and less privacy (Kim \& de Dear 2013). Compared with workers positioned at permanent workstations in open plan offices, those working in activity-based offices can choose a workstation based on what best suits their current task. They thus have more control over their work, which earlier research has linked to better health and well-being (Jones \& Fletcher 2003). On the other hand, self-assessed employee productivity in activity-based offices is adversely affected when the floor plan does not allow smooth interaction with colleagues, does not permit the employees to individualize workstations, and offers insufficient storage space. These factors are considered to more negatively affect productivity than not having a permanent workstation (Brunia et al. 2016, Kim et al. 2016). The physical design and comfortable furnishings of the workplace also affect staff's self-assessed health in activity-based offices (Kim et al. 2016).

Jacqueline Vischer (2007) has developed the so-called environmental comfort model that relates psychosocial aspects to design of the physical environment and leadership using the concepts: territoriality, privacy and control. By territoriality, Vischer refers to the feeling of belonging to the workplace, whereas privacy refers to the possibility of controlling one's accessibility to others. Control refers to both the ability to control the physical environment (regulate light, sound, tables, chairs, etc.) and empowerment of employees, i.e. employee involvement and ability to influence and control (cf. Dale 2005). Vischer (2007) uses the term "environmental fit", i.e. the extent to which different factors in the physical environment are adapted to the individual's work. The model postulates that employees will experience stress in a physical environment that is poorly adapted for performing the tasks (Vischer 2007).

\subsection{Consequences of office relocations}

In the Swedish context a pre- and post-evaluation of a psychiatric unit relocation was conducted by researchers at Occupational and Environmental Medicine, Uppsala University (Stöllman, Eriksson \& Vingård 2015). The evaluation was done by focus group interviews to capture the staff's experience about four months before and about fourteen months after the move. The main advantage after the move was that collaboration had been facilitated by proximity to each other (Stöllman, Eriksson \& Vingård 2015). The concerns reported prior to relocation were confirmed in post-relocation interviews. Staff reported difficulties in concentrating in the open plan offices due to noise disturbances. Generally, work in open plan offices caused deterioration in the psychosocial and physical environment, for example, lack of daylight in several workplaces. Organizational hierarchy became clearer because the management had more privacy in the office space, had high ceilings and better lighting compared to other employees' more crowded and darker workplaces. The majority of the staff desired a cell office in order to work efficiently. 
These results are in line with previous research on relocation projects, which finds that the trend towards open offices has a measurably negative effect on office employees' performance (Vischer 2003).

In contrast, a three-wave diary study including Austrian office workers showed that a fit between office environment and activities is a precondition for achievement of beneficial effects when relocating to an activity-based office environment (Gerdenitsch, Korunka \& Hertel 2017). This is in line with findings from another study which showed that the small group of workers who switched workstations several times a day were more satisfied with their activity-based work environment than their colleagues (Hoendenvanger et al. 2016). Further, Wohlers \& Hertel (2017) point out the importance of management encouragement of employees to use the activitybased environment as intended.

\subsection{Activity-based offices at universities - an increasing trend}

Research on the academic workplace and its change has advanced further in the Anglo-Saxon world than in Sweden (Price \& Fortune 2008, Pinder et al. 2009, Gorgievski et al. 2010, Haynes et al. 2011, Baldry \& Barnes 2012, Hutson \& McAlinden 2013, Samson 2013, Wilhoit et al. 2016, Vitasovich et al. 2016). The design of the academic workplace is changing as academic activities evolve towards being more transdisciplinary and collaborative, and more dependent on group work and communication than solitary individual work (Pinder et al. 2009, Samson 2013). On the other hand, a great deal of academic work consists of individual work that demands an environment that enables concentration. Many teachers and researchers also need to have access to a sizeable amount of material such as books, articles, notes and the like.

A survey of 18 universities conducted by the Swedish Association of University Teachers and Researchers (SULF) shows that open offices for teachers and researchers are not yet common (Forsberg 2015). About 44\% of higher education institutions had no type of open offices. A similar proportion had some type of open offices, usually small and medium-sized open plan offices for technical and administrative staff, or doctoral students and visiting researchers. Simultaneously, it is stated that the trend is towards open office solutions within the university sector, which has led to a growing concern among university employees, mainly because the existing open offices described in media failed to facilitate focused work (see e.g. Billing 2015, Forsberg 2016). The fact that universities in Sweden follow the trend towards open office solutions is mainly because premises are an increasing part of the costs for higher education institutions. From a management perspective, open office solutions have several advantages; e.g. they are cheaper to build, it is easier to install ventilation and central heating, there is less unused space and it is easier to have a visual overview of the workplace. The current development coincides with the establishment of the New Public Management philosophy, which has resulted in managerialism replacing collegial governance within academia (Baldry \& Barnes 2012, Lorenz 2012). Until now there has not been a serious debate about workplace design and new ways of working within academia in Sweden. There is a fine balance between reducing local costs by decreasing office space and maintaining the ability of teachers and researchers to work efficiently (Pinder et al. 2009, Vitasovich et al. 2016).

The establishment of activity-based offices has occurred without due reflection in the Swedish office market. Previous research emphasizes the importance of doing pre- and postassessments to investigate how the change supports work tasks, affects the psychosocial work environment and employee performance (Vischer 2003). When only post-assessment is conducted it is not possible to measure the effect of the relocation on employees' work situation (Månsson \& Nyberg 2014). Moreover, there is little research on changes in office design within academia and how it affects employees' psychosocial work environment (Gorgievski et al. 2010). Thus, it is unclear what effect relocation to new office premises has on employees' psychosocial work environment and the conditions for working and collaborating in a satisfactory manner. Our research expectations were that the staff would primarily experience changes in the physical 
work environment, such as fewer opportunities for personalizing the workplace, more disturbances, but also that the new environment could be perceived as supporting social interactions better than before the change. In relation to the psychosocial working environment, we expected improved social relations, while quantitative job demands, influence, opportunities for development and work-family relations probably would be unchanged. Finally, we wondered whether the sum of the changes would influence attitudes to work and the workplace.

The purpose of this study is to contribute to knowledge about the importance of the physical work environment for the psychosocial work environment within academia by analyzing how staff at a large Swedish university experience the working environment before and after moving from cell offices to activity-based offices.

\section{Research methods and data collection}

In 2009, the process of planning new premises for the university was initiated and staff representatives declared that they preferred cell offices with access to daylight. As a result, the architect office winning the competition presented a plan including 420 cell offices with daylight. In 2012, however, the senior management decided to discard the cell office concept and invest in open flexible office environment with activity-based workplaces. Three years later, the new premises were taken into use. A broad range of different arrangements were quickly implemented, including a combination of open plan and activity-based workplaces.

\subsection{Participants}

A web-based survey was distributed by using mailing lists to all employees at two faculties three months before relocation and nine months after relocating to new premises (May 2015 and June 2016 respectively). In total, 217 people participated in 2015 (response rate 51\%), whereas 200 people participated in 2016 (response rate 47\%). Table 1 shows participants' gender and age on the two occasions.

\section{TABLE 1}

There were no significant differences regarding gender, age, faculty or time spent on different assignments between respondents in 2015 and 2016.

\subsection{Material}

A questionnaire was designed for investigating the expectations prior to the relocation as stated in the introduction. The questionnaires were identical in 2015 and 2016, except for two questions, asked only in 2016, about where a person usually sat in the workplace, and about which type of workplace a person preferred. Questions on working environment factors such as quantitative job demands, influence, work relations, work-home balance, commitment to the workplace and job satisfaction were obtained from Copenhagen Psychosocial Questionnaire COPSOQ II and the Swedish validation study (Pejtersen et al. 2010, Berthelsen et al., Berthelsen et al. 2014b). Most items were rated on a Likert scale consisting of five response alternatives, except work-home balance consisting of only four response alternatives. Responses were scored in the analysis at $0-25-50-75-100$. Scale points were calculated as the average of the items within each scale, provided that at least half of the items were answered (Pejtersen et al. 2010, Berthelsen et al. 2014a). Further an item on how many days a week the respondent on average worked from home (six response alternatives from never to five days a week scored 0-6) was included. Details regarding the number of items included in the scales and Cronbach's alpha statistics are shown in Table 2. 
The following questions and scales were taken from Bodin Danielsson (2010): Cohesion (two questions), Workplace design (three questions), Workplace premises a) contribute to group feeling, b) contribute to personal job satisfaction, and c) facilitate contacts within the group. Moreover, two self-designed questions were included: whether premises facilitate contacts with other groups and contribute to cohesion at the workplace. Sleep quality was measured with the question: How would you rate your sleep quality in general? Ratings were made on a four-degree Likert scale from very good to very bad.

Problems in the physical work environment were investigated with four questions, e.g. whether a person is bothered by lack of opportunity for privacy. Moreover, we added a separate question about whether a person was bothered by colleagues' conversations or phone calls. Recovery was covered by three items, e.g. whether the respondent felt rested and recovered when restarting work after a couple of days leave. All these items were rated on a five-point scale from always to never/almost never on a Likert scale. The possibility of decorating the workplace was assessed with a question with five response alternatives from to a very high extent to a very small extent. Concern about disturbing others was assessed with a question previously used by the Danish National Research Centre for Work Environment (unpublished) with five response alternatives from to a very high extent to a very small extent. A question about space for humor and laughter in a person's workplace was also included, with five response alternatives ranging from a very high extent to a very low extent (Berthelsen et al., Berthelsen et al. 2014b).

The questionnaire can be accessed by sending a request to the corresponding author.

\subsection{Statistical analysis}

Data were analyzed with IBM SPSS version 22. The analysis included descriptive statistics in terms of mean and standard deviations for psychosocial work environment scales in 2015 and 2016 and frequency distributions for other variables. Differences between the 2015 and 2016 responses for parametric data were analyzed by t-test. Differences in non-parametric data were analyzed by chi ${ }^{2}$-test. The scales' internal consistency was evaluated with Cronbach's alpha.

\section{Results}

In the survey from 2016, the majority responded that they had their own room (74\%) before the move, and most responded that they would prefer this (58\%), while one-quarter responded that they would prefer the new office solution. In the new premises, almost all (86\%) always sat in the same place or in a place where they usually sat if it was vacant, while only a few indicate that they sat where there was a free space. As far as differences before (2015) and after the move (2016) were concerned, employees were working from home to a greater extent in 2016 (see Table 2). There were also a number of significant differences regarding the psychosocial work environment that indicated deterioration of various factors in 2016 compared with 2015. Social community at work had decreased and social support from colleagues was perceived to be lower. Even the social support from the immediate supervisor had decreased in one faculty. Participants felt less involved in the workplace, i.e., they would recommend others to a lesser extent to apply for employment at the workplace, and they were more likely to seek new jobs now than before the move. Furthermore, job satisfaction among the participants had decreased.

\section{TABLE 2}

Common coffee breaks at work had become more rare; $61 \%$ responded that they rarely or never had a common break in 2016 compared with 36\% before the move 2015 ( $p<0.001$ ). Cohesion between groups in the workplace had deteriorated; the proportion responding that cohesion was 
poor increased from $35 \%$ to $51 \%(\mathrm{p}<0.01)$. There was also a strong tendency towards less space for humor and laughter in the workplace; $36 \%$ responded that there was space for humor and laughter to a very small extent or not at all in 2016 compared to $27 \%$ in 2015 ( $p=0.051$ ). Furthermore, it emerged that various aspects of the physical workplace were perceived as significantly poorer after the move, see Table 3. For example, employees were more concerned about disturbing others, while they felt that the opportunity to concentrate on work had deteriorated after the move. Many were bothered by the lack of privacy, feeling that they were being listened to and observed. The workplace's layout was perceived to be poorer after the move and the premises were perceived to a lesser extent to facilitate social contact, cohesion and job satisfaction.

\section{TABLE 3}

\section{Discussion}

In view of the ongoing development of open office solutions, such as activity-based offices, for teachers and researchers in colleges and universities (Price \& Fortune 2008, Pinder et al. 2009, Gorgievski et al. 2010, Haynes et al. 2011, Baldry \& Barnes 2012, Hutson \& McAlinden 2013, Samson 2013, Stöllman et al. 2015, Wilhoit et al. 2016, Vitasovich et al. 2016), the purpose of the current study was to investigate how the employees at a university in Sweden experienced the psychosocial and physical working environment before and after moving to activity-based open office environments. Because the phenomenon of open offices within academia is relatively new, there is a need for studies that investigate the consequences of this type of office solutions for teachers' and researchers' work environment.

Considering that the majority always sit at the same desk, the results show that the employees have challenged the activity-based office solution, whereas other employees seem to challenge the activity-based solution by working mostly from home. The results of the study show that several aspects of the psychosocial and physical working environment were perceived as significantly poorer after the move than before. Many employees worked more often from home, which in turn can lead to further deterioration of the psychosocial work environment. Certain aspects such as the job demands have not changed significantly over the years; however, it can also be stated that no aspects either in the psychosocial or physical working environment were perceived to be better after the move. Since the post-relocation assessment was made nine months after the move to the new premises, which is a relatively long time compared with previous research, it is reasonable to assume that the current results are not reactions to the actual relocation process, but indicate actual worsening of the working environment between the two assessments (Oldham \& Brass 1979).

How can these results be interpreted and what practical relevance do the significant differences between the pre- and post-evaluation have? The psychosocial working environment was investigated with items/scales from COPSOQ, which have been developed for use in research and in practice, for example in connection with risk assessments and impact assessment of organizational changes (Pejtersen et al. 2010). To gain an idea of the results in addition to statistical significance, the concept of "minimal important score difference" can be used, which is applied in medical and epidemiological research (Juniper et al. 1994). Previous research has shown that differences of 5-10 points on most COPSOQ scales (scale 0-100) can be considered to be relevant differences in the working environment (Kristensen 2010, Pejtersen, Bjorner \& Hasle 2010). Against this background, the differences in this study on community at work, commitment to the workplace and job satisfaction were not only statistically significant but also represent a noticeable difference in the workplace. 


\subsection{Results in relation to previous research}

The results of the present study are in line with previous research in that several factors of workplace environment have deteriorated after moving to open plan offices (Oldham \& Brass 1979). The participants perceived social community at work as well as social support from colleagues as lower after the move. In one of the faculties even the support from superior had decreased. This is in line with Morrison \& Mackay's study (2017) showing that when the office environment became more flexible, support from the superior was perceived as lower and relationships between employees did not improve. Further, both resources at work, particularly social community and cohesion, as well as positive outcomes, such as job satisfaction and commitment to the workplace, worsened after moving to new activity-based offices. In an earlier study Bodin Danielsson et al. (2015), found a higher risk of conflicts in activity-based offices, particularly among women. The fact that participants in this study report that coffee breaks are less common, that cohesion between different groups has become poorer and that the occurrence of humor and laughter has decreased together contribute to the likelihood of more workplace conflicts in the future.

In line with previous research (Brunia et al. 2016, Kim et al. 2016) it could also be expected that employees' control over their own work had increased due to the ability to choose workstations in the activity-based office, but no such results were found in this study. While job demands, such as the workload and conflict between work and private life, did not differ before and after relocation, respondents seem to be more concerned with other post-relocation stressors, e.g. those relating to office design. For example, the inclination to work more at home can be interpreted as a coping strategy for the individual, dealing with a poorer balance between demands and resources in relation to work (Kaarlela-Tuomaala et al. 2009), and may be seen as an attempt at adaptation between person and environment (Vischer 2007, Tak 2011).

The participants also perceived various aspects of the physical work environment as poorer after the move. They were more afraid of disturbing others, had difficulties in concentrating on their own work and were bothered by lack of privacy. Kim and de Dear (2013) found that cell offices were better than open plan offices in terms of the physical indoor environment, particularly the acoustic environment and the possibility of privacy. The workplace's layout was perceived to be poorer after the move and the premises were perceived to a lesser extent to contribute to social contact, cohesion and job satisfaction. The results are in line with a previous longitudinal study (Kaarlela-Tuomaala et al. 2009), which shows e.g. that the negative acoustic environment in an open plan office led to several disturbances such as reduced integrity and more concentration difficulties at the same time as the anticipated positive effects such as increased cooperation did not occur. The authors conclude that "the open plan office is not recommended for professional workers" (Kaarlela-Tuomaala et al. 2009, p. 1423).

It is difficult to compare the results of this study with previous research in the field because the majority of previous studies were done in other kinds of workplaces than universities (Brill \& Weidemann 2001, Vischer 2003). The few studies done in Sweden within academia have been mainly qualitative interview surveys (Stöllman, Eriksson \& Vingård 2015). One may ask whether and in what way the academic workplace differs from other workplaces and what significance this would have for the choice of office space (Gensler 2012). Like many types of work, academic work consists partly of individual work (reading, writing, assessing, and analyzing data) and partly of interacting with others (teaching, informal and formal meetings). One difference is that many teachers and researchers have considerable material in the form of books, notes and the like that they need access to in their work. Because activity-based offices are assumed to be paperless environments where most material is digitalized (Toivanen 2015), a conflict arises because digitalization of academic activities has not yet come so far. Another difference is that a large part of academic work demands an environment that enhances concentration. Earlier research has 
deemed open offices as less suitable for work demanding concentration (De Been \& Beijer 2014, Gensler 2012, Seddigh et al. 2015).

\subsection{Study limitations and strengths}

One limitation of the study is the two-wave cross-sectional design, which does not allow for causal conclusions. Another limitation is that the survey was sent as a link to employees on the faculties' mailing lists and we are thus not sure whether all relevant persons have received the link. This means that we cannot calculate the exact response rate or do a non-response analysis.

Further, it can be discussed whether the perceived differences in the psychosocial work environment are caused by the relocation or by other changes that occurred in the organization between the assessments that may have affected the results. For example, a centralization of administrative functions in the organization took place, which may have affected the social relations in the workplace to some extent.

However, the participants consist of essentially the same group of employees and managers with the same work tasks and work resources before and after the relocation from one place to another. The analyses also showed that the composition of participants in 2015 and 2016 did not differ significantly regarding faculty membership, gender, age distribution or time spent on different assignments. This strengthens the reliability of the results, i.e. that they are related to the changes in the workplace rather than changes in the composition of the study population during the two study years. Moreover, it may be assumed that, although the overall relocation process has been the same for everyone, local interpretation and leadership style have influenced how the staff perceived the change. All in all, it is important to be careful when generalizing the results.

One strength is that the study has mainly used validated items, though low internal consistency (Cronbach alpha) values below 0.60 were found for two scales consisting of two items each. Despite this, we chose to add them into a scale as the items address different though related aspects of the underlying concept. However, for future studies it would be recommendable to include all items included in the COPSOQ scales for better reliability. We believe it is a strength that assessments are done both before and after moving to the activitybased office. Most previous studies have been limited by comparisons between different types of workplaces (Bodin Danielsson \& Bodin 2009, Seddigh et al. 2014), whereas we have had the opportunity to follow the relocation of one workplace.

The main contribution of our study is that it provides new knowledge of a contemporary phenomenon that affects the physical and psychosocial work environment of thousands of university employees, their collaboration and opportunities to carry out their work satisfactorily. The current results, together with previous research, emphasize the importance of careful preparation prior to major changes in the working environment and of ensuring employee involvement in the change process (Pinder et al. 2009, Toivanen 2015, Morrison \& Macky 2017).

In addition to physical factors, how employees experience new office space depends largely on how the change process and the relocation are handled (Brunia et al. 2016). Previous research suggests that the following factors are addressed in relocation projects: 1) the change is initiated, communicated and clearly guided by senior management, 2) a thorough analysis of existing premises and working methods is done and 3) employee involvement in the change process is ensured (Toivanen 2015). The planning process for the relocation analyzed in the current study started in 2009 and was based on employees' involvement. Both employees and first-line managers were in favor of cell offices and this was also the initial plan, and the criteria for a competition for architect companies in 2010. The winning project suggested the current building, but consisting of 420 cell offices with natural daylight. Two years later, in 2012 without a prior involvement of employees, the vice-chancellor decided on a revision of the plans, namely that activity-based offices would replace the plans of cell offices. Despite a consequence analysis pointing to potential problems with the new plan, it was executed, resulting in activity-based offices. In relation to the three factors mentioned above, it is obvious that the employees were 
involved in the initial part of the process, but the decision from senior management overruled their ideas. Even though a consequence analysis was conducted, a thorough analysis of working methods and needs was not initiated and integrated in the interior design. Taken together, these issues may have contributed to the resistance to moving into the new premises and to the decreased job satisfaction (Brunia et al., 2016).

\section{Implications for practice}

Several universities plan to introduce open office solutions, such as activity-based offices, for teachers, researchers and other staff, with the justification that it saves money and meets future needs. Based on the results of this study, there is reason to be cautious about such change processes and the way they are implemented. The savings that the organization may achieve in costs for premises may lead to costs in other ways. The risk that staff do not like their workplace, cannot concentrate on their work and lose their sense of social community at work are factors which in the long run can lead to decreased efficiency, more conflicts and poorer well-being.

\section{References}

Appel-Meulenbroek, R., Groenen, P., Janssen, I. (2011), "An end-user's perspective on activity-based office concepts", Journal of Corporate Real Estate, Vol. 13 No. 2, pp. 122-135.

Baldry, C., Barnes, A. (2012), "The open-plan academy: Space, control and the undermining of professional identity", Work, Employment and Society, Vol. 26 No. 2, pp. 228-245.

Berthelsen, H., Westerlund, H., Søndergård Kristensen, T. (2014a), COPSOQ II: en uppdatering och språklig validering av den svenska versionen av en enkät för kartläggning av den psykosociala arbetsmiljön på arbetsplatser, Stressforskningsinstitutet, Stockholms universitet, Stockholm.

Berthelsen, H., Lönnblad, A., Hakanen, J., Søndergård Kristensen, T., Axtelius, B., Bjørner, J.B., Westerlund, H. (2014b), "Cognitive interviewing used in the development and validation of Copenhagen Psychosocial Questionnaire in Sweden" in The 7th Nordic Working Life Conference - Stream 26: Methodological challenges for working life and labour market studies, Göteborg, Sweden.

Billing, M. (2015), "Öppna kontorslandskap ett globalt problem". Dagens Nyheter.

Bodin Danielsson, C., Bodin, L. (2008), "Office Type in Relation to Health, Well-Being, and Job Satisfaction Among Employees", Environment \& Behavior, Vol. 40 No. 5, pp. 636-668.

Bodin Danielsson, C., Bodin, L. (2009), "Difference in satisfaction with office environment among employees in different office types", Journal of Architectural and Planning Research, pp. 241-257.

Bodin Danielsson, C. (2010), The office - an explorative study: architectural design's impact on health, job satisfaction \& well-being, KTH, Stockholm.

Bodin Danielsson, C., Chungkham, H.S., Wulff, C., Westerlund, H. (2014), "Office design's impact on sick leave rates", Ergonomics, Vol. 57 No. 2, pp. 139-147.

Bodin Danielsson, C., Bodin, L., Wulff, C., Theorell, T. (2015), "The relation between office type and workplace conflict: A gender and noise perspective", Journal of Environmental Psychology, Vol. 42, pp. 161-171.

Brill, M., Weidemann, S. (2001), Disproving widespread myths about workplace design, Kimball International, Jasper.

Brunia, S., De Been, I., van der Voordt, T.J.M. (2016), "Accommodating new ways of working: lessons from best practices and worst cases", Journal of Corporate Real Estate, Vol. 18 No. 1, pp. 30-47.

Dale, K. (2005), "Building a social materiality: Spatial and embodied politics in organizational control", Organization, Vol. 12 No. 5, pp. 649-678.

De Been, I., Beijer, M. (2014) "The influence of office type on satisfaction and perceived productivity support." Journal of Facilities Management Vol. 12 No. 2, pp.142-157.

Forsberg, B. (2015), "Kontorslandskap fortfarande ovanligt inom högskolan", Universitetsläraren. https://universitetslararen.se/2015/10/12/kontorslandskap-fortfarande-ovanligt-inom-hogskolan/

Forsberg, B. (2016), "Kritik mot öppna kontorslandskap på nytt campus Chalmers", Universitetsläraren. https://universitetslararen.se/2016/03/01/kritik-mot-oppna-kontorslandskap-pa-nytt-campus-chalmers/

Gensler (2012), What we've learned about focus in the workplace: Gensler Research. ttps://www.gensler.com/.../Focus_in_the_Workplace

Gerdenitsch, C., Korunka, C., \& Hertel, G. (2017). Need-Supply Fit in an Activity-Based Flexible Office: A Longitudinal Study During Relocation. Environment and Behavior, pp. 1-26.

Gorgievski, M., van der Voordt, T., van Herpen, S., van Akkeren, S. (2010), "After the fire. New ways of working in an academic setting", Facilities, Vol. 28 No. 3-4., pp. 206-224.

Gunne, N. (2013), "Gränslöst - De aktivitetsbaserade kontoren har kommit till Sverige", Arkitekten, Vol. 11, pp. $32-37$. 
Haynes, B.P., Parkin, J.K., Austin, S.A., Pinder, J.A., Baguley, T.S., Allenby, S.N. (2011), "Balancing collaboration and privacy in academic workspaces", Facilities, Vol. 29 No. 1,2., pp. 31-49.

Hoendervanger J.G., De Been I, Van Yperen N.W., Mobach M.P., Albers C.J., (2016) "Flexibility in use: Switching behaviour and satisfaction in activity-based work environments", Journal of Corporate Real Estate, Vol. 18 Issue: 1, pp. 48-62

Hutson, A., McAlinden, A. (2013), "Workshopping the workspace: Consultation in designing the shared academic workplace", Association for Tertiary Education Management and Tertiary Education Facilities Managers' Association, Vol. 107.

Jahncke, H., Hygge, S., Halin, N., Green, A.M., Dimberg, K. (2011), "Open-plan office noise: Cognitive performance and restoration", Journal of Environmental Psychology, Vol. 31 No. 4, pp. 373-382.

Jones, F., Fletcher, B.C. (2003), Job Control, Physical Health and Psychological Well-Being, in Schabracq, M., Winnubst, J.A.M, and Cooper, C.L. (Ed.), The handbook of work and health psychology, J. Wiley \& Sons, Chichester, pp. 121-142.

Juniper, E.F., Guyatt, G.H., Willan, A., Griffith, L.E. (1994), "Determining a minimal important change in a disease-specific quality of life questionnaire", Journal of Clinical Epidemiology, Vol. 47 No. 1, pp. 8187.

Kaarlela-Tuomaala, A., Helenius, R., Keskinen, E., Hongisto, V. (2009), "Effects of acoustic environment on work in private office rooms and open-plan offices - longitudinal study during relocation", Ergonomics, Vol. 52 No. 11, pp. 1423-1444.

Kim, J., de Dear, R. (2013), "Workspace satisfaction: The privacy-communication trade-off in open-plan offices", Journal of Environmental Psychology, Vol. 36, pp. 18-26.

Kim, J., Candido, C., Thomas, L., de Dear, R. (2016), "Desk ownership in the workplace: The effect of nonterritorial working on employee workplace satisfaction, perceived productivity and health", Building and Environment, Vol. 103, pp. 203-214.

Kristensen, T. (2010), "A questionnaire is more than a questionnaire", Scandinavian Journal of Public Health, Vol. 38 No. 3, pp. 149.

Kupritz, V. (2001), "Aging worker perceptions about design and privacy needs for work", Journal of Architectural and Planning Research, Vol. 18 No. 1, pp. 13-22.

Lorenz, C. (2012), "If you're so smart, why are you under surveillance? Universities, neoliberalism, and new public management", Critical Inquiry, Vol. 38 No. 3, pp. 599-629.

Månsson, J., Nyberg, C. (2014), En studie av det aktivitetsbaserade arbetssättet-Implementeringsprocess, effektmål, nyckeltal \& Goal Evaluation Model. Examensarbete inom kandidatprogram, Institutionen för arkitektur, Avdelningen för byggnad, Chalmers Tekniska Högskola, Göteborg.

Morrison, R.L., Macky, K.A. (2017), "The demands and resources arising from shared office spaces", Applied Ergonomics, Vol. 60, pp. 103-115.

Oldham, G.R., Brass, D.J. (1979), "Employee Reactions to an Open-Plan Office: A Naturally Occurring QuasiExperiment", Administrative Science Quarterly, Vol. 24 No. 2, pp. 267-284.

Pejtersen, J.H., Bjorner, J.B., Hasle, P. (2010), "Determining minimally important score differences in scales of the Copenhagen Psychosocial Questionnaire", Scandinavian Journal of Public Health, Vol. 38 No. 3 , pp. 33-41.

Pejtersen, J.H., Kristensen, T.S., Borg, V., Bjorner, J.B. (2010), "The second version of the Copenhagen Psychosocial Questionnaire", Scandinavian Journal of Public Health, Vol. 38 No. 3, pp. 8-24.

Pejtersen, J.H., Feveile, H., Christensen, K.B., Burr, H. (2011), "Sickness absence associated with shared and open-plan offices - a national cross sectional questionnaire survey", Scandinavian Journal of Work, Environment \& Health, Vol. 37 No. 5, pp. 376-382.

Pinder, J., Parker, J., Austin, S.A., Duggan, F., Lansdale, M., Demian, P., Baguley, T., Allenby, S. (2009), The case for new academic workspace, Loughborough University, Loughborough.

Price, I., Fortune, J. (2008), "Open plan and academe: pre-and post-hoc conversations", in W070 conference: healthy and creative facilities.

Samson, D. (2013), "From the Ivory Tower to Activity Based Workspaces", International Journal of Information and Education Technology, Vol. 3 No. 6, pp. 624.

Seddigh, A., Berntson, E., Bodin Danielsson, C., Westerlund, H. (2014), "Concentration requirements modify the effect of office type on indicators of health and performance", Journal of Environmental Psychology, Vol. 38, pp. 167-174.

Seddigh, A., Stenfors, C., Berntsson, E., Bååth, R., Sikström, S., Westerlund, H. (2015), "The association between office design and performance on demanding cognitive tasks", Journal of Environmental Psychology, Vol. 42, pp. 172-181.

Slunga Järvholm, L. (2016), "Aktivitetskontor passar inte alla", SVT Nyheter, Västerbotten.

Stöllman, Å., Eriksson, T., Vingård, E. (2015), Flytten till Psykiatrins hus - arbetsmiljön i öppna arbetsplatser, Uppsala: Arbets- och miljömedicin, Akademiska sjukhuset, Uppsala universitet.

Stone, P.J., Luchetti, R. (1985), "Your office is where you are", Harvard Business Review, Vol. 63 No. 2, pp. 102-117. 
Tak, J. (2011), "Relationships between various person-environment fit types and employee withdrawal behavior: A longitudinal study", Journal of Vocational Behavior, Vol. 78 No. 2, pp. 315-320.

Toivanen, S. (2015), Framtidens arbetsplatser - att utveckla hållbara och friska kontor, Susanna Toivanen, Stockholm.

Van der Voordt T.J.M. (2004) "Productivity and employee satisfaction in flexible workplaces", Journal of Corporate Real Estate, Vol. 6 Issue: 2, pp. 133-148

Vischer, J.C. (2003), "Designing the work environment for worker health and productivity", International Academy for Design and Health, 2003, pp. 85-93.

Vischer, J.C. (2007), "The effects of the physical environment on job performance: towards a theoretical model of workspace stress", Stress \& Health: Journal of the International Society for the Investigation of Stress, Vol. 23 No. 3, pp. 175-184.

Vitasovich, A., Kiroff, L., Boon, J. (2016), "The adoption of modern office workspaces by tertiary education institutes: a case study of Unitec", $40^{\text {th }}$ Australasian Universities Building Education Association (AUBEA) Conference, 6-8 July, Cairns, Australia, pp 797-807.

Wilhoit, E.D., Gettings, P., Malik, P., Hearit, L.B., Buzzanell, P.M. (2016), "STEM faculty response to proposed workspace changes", Journal of Organizational Change Management, Vol. 29 No. 5, pp. 804-815.

Wohlers C., Hertel G (2017). Choosing where to work at work - towards a theoretical model of benefits and risks of activity-based flexible offices. Ergonomics Vol. 60 , Iss. 4,. Pp. 467-486 
Table 1. Background information about the participants

\begin{tabular}{lcccc}
\hline & 2015 & & 2016 \\
No. $(\boldsymbol{n})$ & Proportion (\%) & No $(\boldsymbol{n})$ & Proportion (\%) \\
\hline Sex & & & & 54 \\
Female & 119 & 56 & 106 & 46 \\
Male & 95 & 44 & 89 & \\
& & & & 7 \\
Age & & 11 & 13 & 75 \\
25-34 years & 23 & 71 & 149 & 19 \\
35-54 years & 154 & 18 & 37 & \\
55+ & 39 & & & \\
\hline
\end{tabular}


Table 2. Differences (t-tests) between 2015 and 2016 regarding psychosocial work environment factors and reliability of the scales.

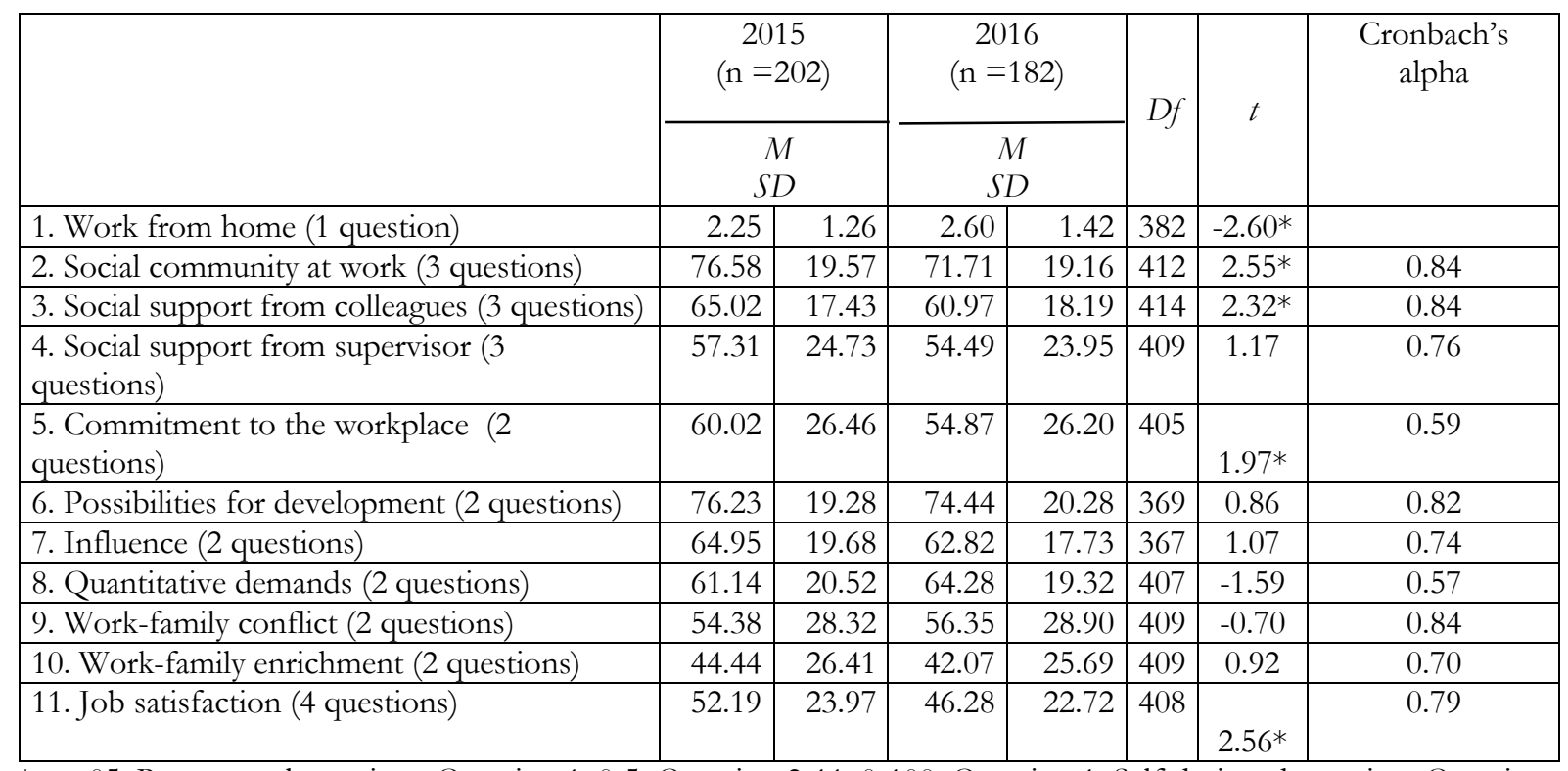

${ }_{* \mathrm{p}}<$.05. Response alternatives: Question 1: 0-5; Question 2-11: 0-100. Question 1: Self-designed question; Question 2-9, 11: Pejtersen et al., 2010; Berthelsen et al., 2014a; Question 10: Berthelsen et al., 2014b. 
Table 3. Differences (Chi ${ }^{2}$ test) between proportions of responses (response alternatives in parantheses for each item) 2015 and 2016 regarding the physical working environment.

\begin{tabular}{|c|c|c|c|}
\hline & $\begin{array}{c}2015 \\
(\mathrm{n}=202) \\
\%\end{array}$ & $\begin{array}{c}2016 \\
(\mathrm{n}=182) \\
\%\end{array}$ & $p$ \\
\hline Possibility of decorating the workplace (to a very small extent-barely) & 21 & 91 & $<0.001$ \\
\hline Worried about disturbing others (to a very high degree) & 10 & 44 & $<0.001$ \\
\hline Opportunity to concentrate at work (often-always) & 61 & 34 & $<0.001$ \\
\hline \multicolumn{4}{|l|}{ Bothered by: } \\
\hline Lack of opportunity for privacy (often-almost always) & 15 & 56 & $<0.001$ \\
\hline Being listened to (often-almost always) & 6 & 42 & $<0.001$ \\
\hline Being observed (often-almost always) & 7 & 33 & $<0.001$ \\
\hline The general noise level (often-almost always) & 11 & 38 & $<0.001$ \\
\hline Colleague's conversation/phone call (often-almost always) & 9 & 40 & $<0.001$ \\
\hline \multicolumn{4}{|l|}{ Workplace design regarding: } \\
\hline Convenience (quite/very bad) & 13 & 35 & $<0.001$ \\
\hline Sitting comfort (quite/very bad) & 15 & 22 & 0.057 \\
\hline Work position (quite/very bad) & 15 & 30 & $<0.01$ \\
\hline \multicolumn{4}{|l|}{ Workplace premises regarding: } \\
\hline Contributes to group feeling (not at all-to some extent) & 58 & 77 & $<0.001$ \\
\hline Facilitates contacts within the group (not at all-to some extent) & 50 & 67 & $<0.001$ \\
\hline Facilitates contacts with other groups (not at all-to some extent) & 58 & 77 & 0.616 \\
\hline Cohesion at the workplace (not at all-to some extent) & 57 & 83 & $<0.001$ \\
\hline Personal job satisfaction (not at all-to some extent) & 46 & 80 & $<0.001$ \\
\hline
\end{tabular}

